Original Article

\title{
In vitro embryogenic callus induction of Carica pubescens Lenne and K.Koch using 2,4-D (2,4-Dichlorophenoxy Acetic Acid) and BAP (6- Benzylaminopurin)
}

\author{
Shinta*, Eko Budi Minarno, I'anatur Rofiqoh \\ Department of Biology, Faculty of Science and Technology, Maulana Malik Ibrahim Malang Islamic State University, \\ Gajayana Street 50, Malang-East Java, Indonesia
}

\begin{abstract}
Carica pubescens Lenne \& K. Koch has benefits as a producer of medicinal compounds. Propagation of C. pubescens is important to be done through in vitro embryogenic callus culture. This research aimed to determine the effect of 2,4-D growth regulators, 2,4-D and BAP interactions on the induction of embryogenic callus $C$. pubescens Lenne \& K. Koch. This research is experimental, using a completely randomized design (CRD) with 25 treatments and 5 replications. Embryonic callus was induced by various concentration of 2,4 D $(0 \mathrm{mg} / \mathrm{L}, 2.5 \mathrm{mg} / \mathrm{L}, 5 \mathrm{mg} / \mathrm{L}, 7.5 \mathrm{mg} / \mathrm{L}$, and $1 \mathrm{mg} / \mathrm{L})$ in combination with BAP $(0 \mathrm{mg} / \mathrm{L}, 2.5 \mathrm{mg} / \mathrm{L}, 5 \mathrm{mg} / \mathrm{L}, 7.5 \mathrm{mg} / \mathrm{L}$, and $1 \mathrm{mg} / \mathrm{L})$. Data were analyzed using two-way ANOVA, followed by the Duncan Multiple Range Test (DMRT) $(p>0.05)$. The result showed that the addition of 2,4 D and BAP as a growth regulator gave an effect on embryonic callus. Concentration of $7.5 \mathrm{mg} / \mathrm{L} \mathrm{2,4} \mathrm{D}$ and $0.5 \mathrm{mg} / \mathrm{L} \mathrm{BAP}$ in callus 19 days after planting showed the most effective interaction of both inductors. The combination produced callus fresh weight at $1.09 \mathrm{~g}$ and $99 \%$ in percentage of explant callus area. Morphological and anatomical observations showed the characteristic of embryogenic callus as indicated by yellowish, textured callus friable, having a large core and containing starch grains also plastids.
\end{abstract}

Keywords: 2,4-D, BAP, Embryogenic callus Carica pubescens Lenne \& K. Koch

Received: 21 March 2020 Revised: 13 April 2020 Accepted: 22 May 2020

\section{Introduction}

Indonesia is one of the countries which has abundant natural resources, both animals and plants. In this country, some plants are used as medicinal plants including Carica pubescens Lenne and K.Koch. Genus of Carica belongs to Caricaceae family that consists of approximately 40 species, and C.pubescens is one of them (Budiyanti et al., 2005). It is a plant from South America and has been widespread to the Andas islands. This plant is often found not only in Bromo and Cangar East Java but also in Dieng Plateau Central Java, Indonesia (Minarno, 2015).

Regarding to Distan (2008) C. pubescens has a useful compound for the body which are carotene, vitamin $\mathrm{C}$, and flavonoid as anti-cancer substances. The content of the papain enzyme serves to break down leftover food fibers and facilitate defecating. C. pubescens fruit is not delicious to be directly consumed because it has a sour and bitter taste though it is ripe. Furthermore, the flesh of the fruit contains a lot of sap that causes itching when it comes to the lips, mouth, and skin (Ngumriana, 2015). Therefore, $C$. pubescens should be processed before eaten, and it becomes the iconic food product from Wonosobo region (Distan, Wonosobo Regency, 2008). Based

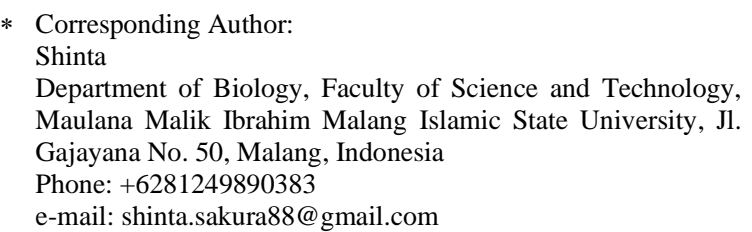

on the data from the Wonosobo Regency, Distan (2008) stated that the total production of $C$. pubescens was 1342.28 tons whereas the average production capacity of Carica processed by small industries in Wonosobo ranges from 1.5 tons to 18 tons per month. Therefore, the production capacity cannot meet consumers' demands. It is because $C$. pubescens plant is a seasonal plant, so its occurrence is often rare in certain seasons (Dewi, 2009).

Propagation of $C$. pubescens plants in Indonesia is still done traditionally or conventionally by using seeds. However, C. pubescens seed germination is difficult to be applied conventionally due to the type of seeds, genetic factors, and environmental factors. Besides, conventional seed germination requires a relatively long time to sprout germination, and it causes an extended maturation of seed dormancy. It is due to the presence of pulp attached to the seeds of $C$. pubescens containing abscisic acid, which is an inhibitor of seed germination and growth. In addition, seeds propagation produce offspring that have different characteristic to the parents (Sari \& Suwarsi, 2014).

The propagation efforts of $C$. pubescens plants has not been investigated yet, so its propagation with embryogenic callus culture should be applied. The embryogenic callus has the potential to become a plant through organogenesis and embryogenesis (Subarnas, 2011). The advantage of somatic embryogenesis culture can produce somatic embryos that have bipolar characteristics, and it has root tips and shoots which are needed in plant growth. In addition, it can produce embryos in large numbers with limited space (Zulkarnain, 2009). Somatic embryogenesis 
regeneration has advantages over bud regeneration (organogenesis). It causes the speed of multiplication of somatic embryogenesis higher, and the process of somatic embryogenesis can last a long time without depending on the source of the explant (Neliyati, 2013). According to Rusdianto and Indrianto (2012) stated that embryogenic callus had the characteristics of a yellowish-white, creamy or milky white, a crumb texture, and there was a large nucleus if it was observed microscopically. Whereas Quiroz et al. (2002) stated that there was a large cell nucleus, having a distance between cells, containing starch grains as well as plastids in the cytoplasm, and having a small vacuole in the embryogenic callus if it was observed microscopically.

The interaction between planting media and appropriate growth regulator will affect callus growth, increase cell division activity in the process of morphogenesis and organogenesis (Fithrotin, 2017; Lestari, 2011). Growth regulator 2,4-Dichlorophenoxy acetic acid is a type of auxin which has more stable properties than other synthetic auxin types. It can stimulate the formation of somatic embryos directly through the surface point of growth of zygotic embryos (Indria, 2017). Damayanti et al., (2007) research results showed that $1 / 2$ MS media + 2,4-D $10 \mathrm{mg} / \mathrm{L}$ could produce the highest Carica papaya embryogenic callus that is $80 \%$. One of the cytokinin groups that is often used in in vitro culture is BAP (6Benzylaminopurin). It is because the nature of BAP is stable, easily obtained and more active. Whereas Mondal et al., (1994) research result showed that the treatment of $0.5 \mathrm{mg} / \mathrm{L}$ BAP and MS media could induce Carica papaya (Var. Honey Dew) callus with a fresh weight of callus $3.5 \mathrm{~g}$. The use of auxiliary and cytokinin ZPT had also been carried out in several embryogenic callus cultures. Further, Haensch's research (2007) research result explained that the embryogenic callus culture Pelargonium $\mathrm{x}$ domesticum on MS media with a concentration of $4 \mathrm{mg} / \mathrm{L}$ 2,4-D + $0.5 \mathrm{mg} / \mathrm{L}$ BAP could induce callus with a wet callus weight of $9.4 \mathrm{mg}$. A sufficient and balanced comparison of 2,4-D and BAP concentrations determined the callus shape and structure. In callus culture, giving ZPT both 2,4-D and BAP is highly expected to induce and increase callus growth so that it can obtain large biomass.

The purpose of this research is to determine the effect of 2,4-Dichlorophenoxy Acetic Acid (2,4-D) and BAP (6Benzylaminopurin) interaction in inducing embryogenic callus of Carica pubescens Lenne \& K. Koch in accordance with In Vitro.

\section{Methods}

This research was conducted at the Tissue Culture Laboratory, Department of Biology, Faculty of Science and Technology, Maulana Malik Ibrahim State Islamic University of Malang. The explants used were young Carica pubescens Lenne \& K. Koch. Whereas the media used were $1 / 2 \mathrm{MS}$, sugar, agar, 2,4-D interactions (concentration $0 \mathrm{mg} / \mathrm{L}, 2.5 \mathrm{mg} / \mathrm{L}, 5 \mathrm{mg} / \mathrm{L}, 7.5 \mathrm{mg} / \mathrm{L}$, and $10 \mathrm{mg} / \mathrm{L})$ and BAP (concentration $0 \mathrm{mg} / \mathrm{L}, 0.25 \mathrm{mg} / \mathrm{L}, 0.5 \mathrm{mg} / \mathrm{L}, 0.75$ $\mathrm{mg} / \mathrm{L}$ and $1 \mathrm{mg} / \mathrm{L}$ ).

\section{Explant Sterilization}

The young seed of $C$. pubescens was cleaned by using a tissue to remove the sticky mucus, then washed with running water for $30 \mathrm{~min}$. Whereas explant was washed with detergent for $15 \mathrm{~min}$ and rinsed with running water. After that, the explant was soaked with a bactericidal solution for $5 \mathrm{~min}$ and rinsed with running water. Then it was immersed in a fungicide solution (benlate $0.5 \mathrm{mg} / \mathrm{L}$ ), shaken for an hour, and rinsed with running water. Further, it was sterilized using a 30\% Clorox solution for 15 min in laminar airflow. Then it was rinsed by using aquades sterile three times for $5 \mathrm{~min}$.

\section{Explant Initiation}

The sterile young seed of $C$. pubescens was taken out from the embryo, then planted on 2,4-D interaction media (concentration $0 \mathrm{mg} / \mathrm{L}, 2.5 \mathrm{mg} / \mathrm{L}, 5 \mathrm{mg} / \mathrm{L}, 7.5 \mathrm{mg} / \mathrm{L}$, and $10 \mathrm{mg} / \mathrm{L}$ ) and BAP (concentration $0 \mathrm{mg} / \mathrm{L}, 2.5 \mathrm{mg} / \mathrm{L}, 5$ $\mathrm{mg} / \mathrm{L}, 7.5 \mathrm{mg} / \mathrm{L}$, and $10 \mathrm{mg} / \mathrm{L}$ ). Each bottle contained two explants with five times of repetition. The culture bottles that had been planted with explant was incubated in the culture storage room at a temperature of $23-25^{\circ} \mathrm{C}$ and incubated for 45 days. The parameter observed was the day of callus formed, percentage of callus area in explants, callus fresh weight, callus color, callus texture and callus anatomy.

\section{Data Analysis}

The data were observed both of qualitatively and quantitatively. Qualitative data was obtained based on visual observation on callus morphology including color, texture and callus anatomy. Those data were analysed descriptively. Whereas, the data such as the days of callus formed, fresh weight, and percentage of callus explants were quantified and analyzed by two ways ANOVA. Post hoc test of Duncan Multiple Range Test (DMRT) was performed when there is significant difference in ANOVA test. Significant value was indicated by $p>0.05$.

\section{Results}

\section{The Day of Callus Formed}

Giving an auxin for callus culture is effective in inducing callus formation, but the role of cytokinin is needed for callus proliferation so that the combination of auxin and cytokinin is very good for stimulating the callus growth (Abidin, 1983). Therefore, it is expected that the combination of 2,4-D and BAP can influence the induction of $C$. pubescens embryogenic callus.

Based on the observations of the day when the callus formed, and the 5\% DMRT test results showed that the effect of 2,4-D and BAP interactions on an explant had a significant effect compared to the control. The combination concentration of 2,4-D 7.5 mg/L and BAP $0.5 \mathrm{mg} / \mathrm{L}$ is the most effective concentration to induce rapid callus, with an average day of callus formed in 19 days after planting. Whereas the longest day for the callus formation is as displayed in Figure 1. 


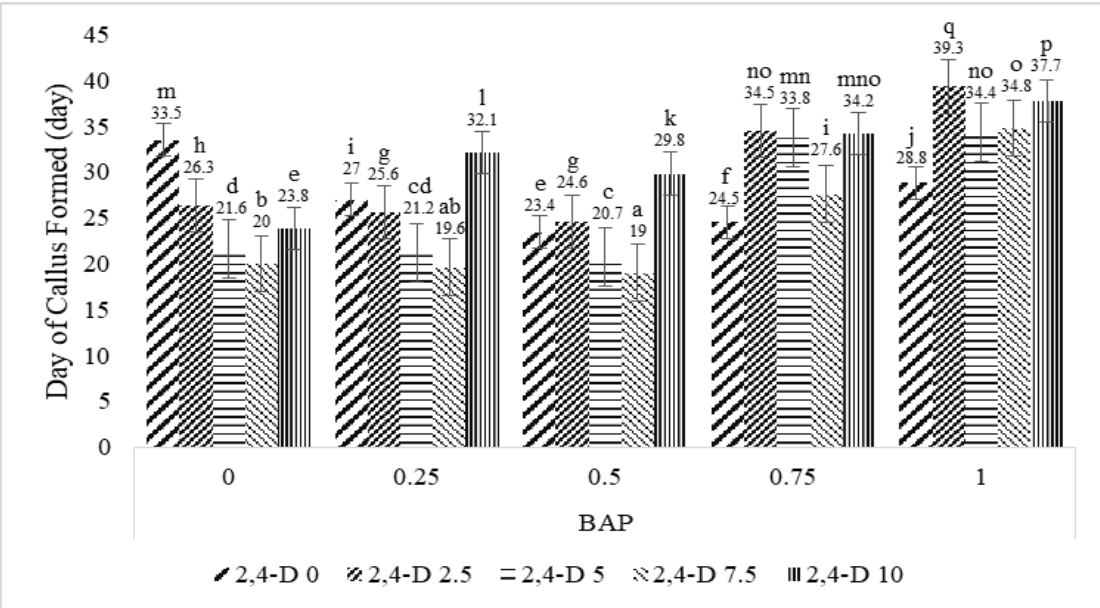

Figure 1. Effect of 2,4-D (ppm) and BAP (ppm) Interactions on the Day of Callus formed. Numbers followed by the same letters indicate no significant difference based on the 5\% DMRT test.

\section{Fresh Weight of Callus}

The result of observation and DMRT $5 \%$ test showed that giving 2,4-D and BAP hormones significantly affected the growth of callus fresh weight. The interaction concentration of $2,4-\mathrm{D} 7.5 \mathrm{mg} / \mathrm{L}$ and BAP $0.5 \mathrm{mg} / \mathrm{L}$ is the most effective concentration for the growth of callus fresh weight, with an average callus fresh weight of $1.09 \mathrm{~g}$ (Fig. 2).

\section{Percentage of Callus Area on Explant}

The optimal cell division may cause optimal callus growth and increase callus fresh weight. It will also affect the percent of callus area in explant because the higher the fresh weight of callus is, the higher of the callus area in explant will be. Observation and DMRT 5\% test showed that giving 2,4-D and BAP hormones significantly affected the percentage of callus area. The interaction concentration of 2,4-D $7.5 \mathrm{mg} / \mathrm{L}$ and BAP $0.5 \mathrm{mg} / \mathrm{L}$ is the most effective concentration for callus percent, with an average callus area percentage of $99 \%$ (Fig. 3).

\section{Morphology and Anatomy of Embryogenic Callus Carica pubescens Lenne \& K. Koch}

The result of the research showed that at the beginning of the callus growth, all treatments showed a white callus, but it experienced a change in color after observing on the day of $45^{\text {th }}$. Based on morphological and microscopic (anatomic) observations, it showed different color, texture and anatomical variables for each treatment. The callus colors produced are brownish yellow, yellowish, brownish-white, yellowish-white, while the result of callus textures is crust, intermediate and compact (Tab. 1). An effective treatment in inducing embryogenic callus at a concentration of $7.5 \mathrm{mg} / \mathrm{L} 2,4-\mathrm{D}+0.5 \mathrm{mg} / \mathrm{L}$ BAP produced a yellowish callus color with crumb callus texture this is evidenced by microscopic observation with a very clear and large cell nucleus that has a round cell shape, and there are starch and plastid grains (Tab. 1 and Fig. 4).

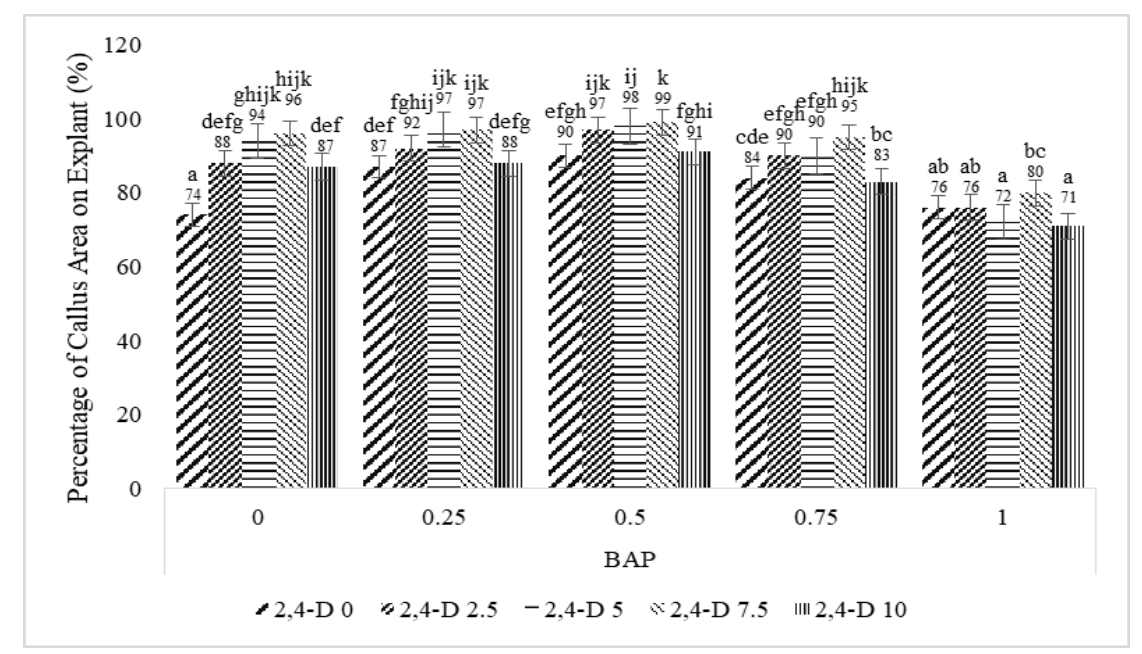

Figure 2. Effect of 2,4-D (ppm) and BAP (ppm) Interactions on Callus Fresh Weight. Numbers followed by the same letters indicate no significant difference based on the $5 \%$ DMRT test. 


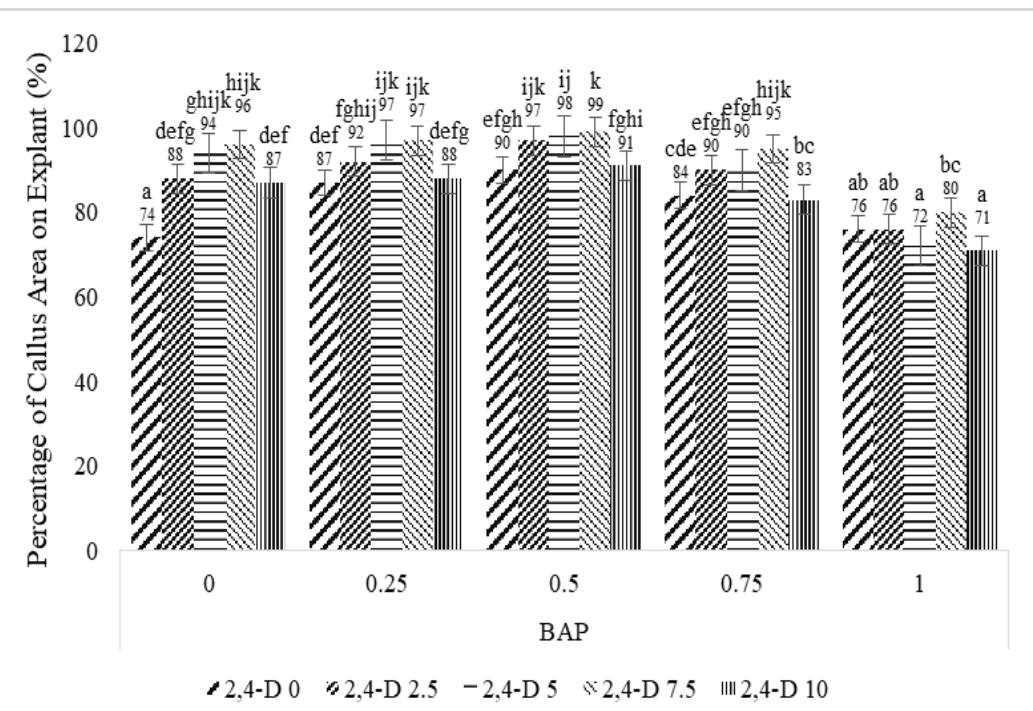

Figure 3. Effect of 2,4-D (ppm) and BAP (ppm) Interactions on the Percentage of Callus Extents on Explants. Numbers followed by the same letters indicate no significant difference based on the 5\% DMRT test.
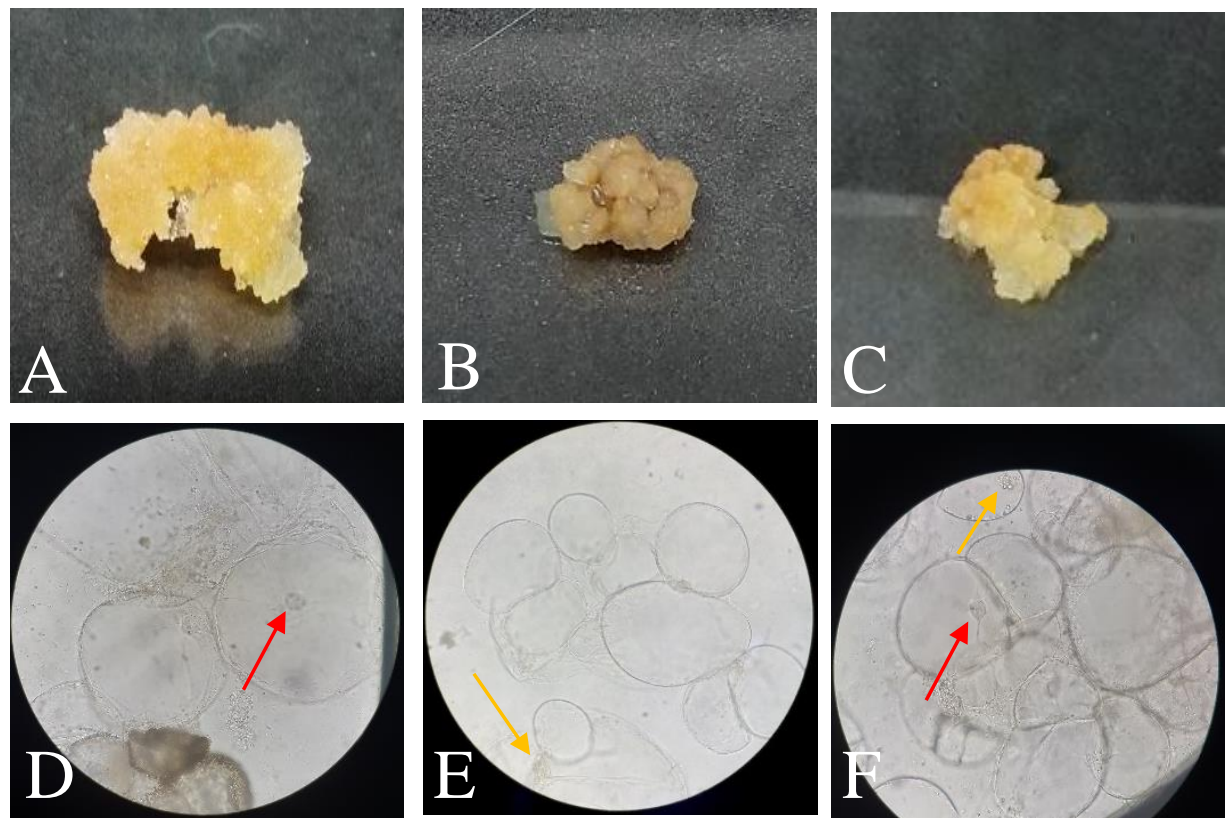

Figure 4. Morphology and Anatomy of Embryogenic Callus C. pubescens 400X, a and d) Crumbs, b and e) Intermediates, c and f) Compact, Red Arrows $=$ Cell nucleus, while Yellow arrows $=$ Plastids.

Table 1. Effect of 2,4-D and BAP Interactions on the Color and Texture of Embryogenic Callus C. pubescens Lenne \& K. Koch.

\begin{tabular}{|c|c|c|}
\hline Treatment & Callus Color & Callus Texture \\
\hline $0 \mathrm{mg} / \mathrm{L} 2,4-\mathrm{D}+0 \mathrm{mg} / \mathrm{L} \mathrm{BAP}$ & Brownish yellow & Intermediate \\
\hline $0 \mathrm{mg} / \mathrm{L} 2,4-\mathrm{D}+0,25 \mathrm{mg} / \mathrm{L} \mathrm{BAP}$ & Yellowish white & Intermediate \\
\hline 0 mg/L 2,4-D + 0,5 mg/L BAP & Brownish yellow & Crumb \\
\hline $0 \mathrm{mg} / \mathrm{L} 2,4-\mathrm{D}+0,75 \mathrm{mg} / \mathrm{L} \mathrm{BAP}$ & Brownish white & Intermediate \\
\hline $0 \mathrm{mg} / \mathrm{L} 2,4-\mathrm{D}+1 \mathrm{mg} / \mathrm{L} \mathrm{BAP}$ & Brownish yellow & Compact \\
\hline $2.5 \mathrm{mg} / \mathrm{L} 2,4-\mathrm{D}+0 \mathrm{mg} / \mathrm{L} \mathrm{BAP}$ & Brownish yellow & Compact \\
\hline $2.5 \mathrm{mg} / \mathrm{L} 2,4-\mathrm{D}+0,25 \mathrm{mg} / \mathrm{L}$ BAP & Brownish white & Compact \\
\hline $2.5 \mathrm{mg} / \mathrm{L} 2,4-\mathrm{D}+0,5 \mathrm{mg} / \mathrm{L} \mathrm{BAP}$ & Brownish white & Crumb \\
\hline $2.5 \mathrm{mg} / \mathrm{L} 2,4-\mathrm{D}+0,75 \mathrm{mg} / \mathrm{L} \mathrm{BAP}$ & Brownish yellow & Crumb \\
\hline $2.5 \mathrm{mg} / \mathrm{L} 2,4-\mathrm{D}+1 \mathrm{mg} / \mathrm{L} \mathrm{BAP}$ & Brownish white & Crumb \\
\hline $5 \mathrm{mg} / \mathrm{L} 2,4-\mathrm{D}+0 \mathrm{mg} / \mathrm{L} \mathrm{BAP}$ & Brownish yellow & Crumb \\
\hline $5 \mathrm{mg} / \mathrm{L} 2,4-\mathrm{D}+0,25 \mathrm{mg} / \mathrm{L} \mathrm{BAP}$ & Yellowish white & Crumb \\
\hline $5 \mathrm{mg} / \mathrm{L} 2,4-\mathrm{D}+0,5 \mathrm{mg} / \mathrm{L} \mathrm{BAP}$ & Yellowish white & Crumb \\
\hline $5 \mathrm{mg} / \mathrm{L} 2,4-\mathrm{D}+0,75 \mathrm{mg} / \mathrm{L} \mathrm{BAP}$ & Yellowish white & Crumb \\
\hline
\end{tabular}




\begin{tabular}{|c|c|c|}
\hline $5 \mathrm{mg} / \mathrm{L} 2,4-\mathrm{D}+1 \mathrm{mg} / \mathrm{L}$ BAP & Yellowish white & Crumb \\
\hline $7.5 \mathrm{mg} / \mathrm{L} 2,4-\mathrm{D}+0 \mathrm{mg} / \mathrm{L}$ BAP & Yellowish white & Crumb \\
\hline $7.5 \mathrm{mg} / \mathrm{L} 2,4-\mathrm{D}+0,25 \mathrm{mg} / \mathrm{L}$ BAP & Yellowish white & Crumb \\
\hline $7.5 \mathrm{mg} / \mathrm{L}$ 2,4-D+ 0,5 mg/L BAP & Yellowish & Crumb \\
\hline $7.5 \mathrm{mg} / \mathrm{L} 2,4-\mathrm{D}+0,75 \mathrm{mg} / \mathrm{L}$ BAP & Yellowish white & Crumb \\
\hline $7.5 \mathrm{mg} / \mathrm{L} 2,4-\mathrm{D}+1 \mathrm{mg} / \mathrm{L}$ BAP & Brownish white & Crumb \\
\hline $10 \mathrm{mg} / \mathrm{L} 2,4-\mathrm{D}+0 \mathrm{mg} / \mathrm{L} \mathrm{BAP}$ & Brownish white & Compact \\
\hline $10 \mathrm{mg} / \mathrm{L} 2,4-\mathrm{D}+0,25 \mathrm{mg} / \mathrm{L} \mathrm{BAP}$ & Brownish white & Crumb \\
\hline $10 \mathrm{mg} / \mathrm{L} 2,4-\mathrm{D}+0,5 \mathrm{mg} / \mathrm{L} \mathrm{BAP}$ & Yellowish white & Compact \\
\hline $10 \mathrm{mg} / \mathrm{L} 2,4-\mathrm{D}+0,75 \mathrm{mg} / \mathrm{L} \mathrm{BAP}$ & Brownish yellow & Compact \\
\hline $10 \mathrm{mg} / \mathrm{L}$ 2,4-D + $1 \mathrm{mg} / \mathrm{L}$ BAP98 & Brownish white & Intermediate \\
\hline
\end{tabular}

\section{Discussion}

A callus is a collection of cells that are not organized, and it occurs due to a very active division. Stimulation of endogenous hormone and growth regulators that are added (exogenous) causes the activation of cell metabolism. In such circumstances, the tissue undergoes differentiation. This situation will continue during callus proliferation (Rivai et al., 2014). The results showed that without the administration of exogenous auxin (2,4-D), the young explant $C$. $p u$ bescens could induce their callus due to the presence of endogenous hormones auxin and cytokines found in $C$. pubescens explant so that it could induce callus without the addition of growth regulators. In addition, the explant used was still young and easy to divide. Planting media that contains nutrients, vitamins and amino acids that are suitable to support the callus growth process. Pratiwi and Rahayu (2013) explained that young explant had meristematic cells that actively divide.

\section{The Day when the Callus Formed}

The results of the research showed that the effect of 2,4-D and BAP interactions on the day of callus formed in explant had a significant effect compared to the control. The concentration combination of 2,4-D $7.5 \mathrm{mg} / \mathrm{L}$ and BAP $0.5 \mathrm{mg} / \mathrm{L}$ is the most effective concentration to induce callus. The callus formation in explant of embryos $C$. pubescens is indicated by swelling of explant which is injured in young embryos by removing the seed coat. According to Sitorus et al., (2012), callus formation occurred because of the injury that occurs in the explant, so the cells which are in the explant will repair the damaged cells. George and Sherrington (1984) suggested that endogenous and exogenous hormones contained in explants supported the occurrence of tissue responses to form a callus. In addition, the callus formation was influenced by the action of auxins and cytokines. The provision of auxin and cytokines that are balanced will have an impact on the callus formation. Therefore, the long callus formation is because the interaction of growth regulators given to the explant is not appropriate to induce callus, so it inhabited callus growth in explant (Zulkarnain, 2009). According to Khaniyah and Habibah (2012), the concentrations of growth regulator, which is too low resulting in the inability to in- duce callus, but it will be toxic to explant if the concentration given is not balanced. Therefore, the combination of the two growth regulators is not suitable to stimulate callus formation.

\section{The Fresh weight and Percentage of Callus Area on Explant}

The fresh weight of the callus indicates a large cell division at concentration. The concentration combination of 2,4-D $7.5 \mathrm{mg} / \mathrm{L}$ and BAP $0.5 \mathrm{mg} / \mathrm{L}$ are the most effective concentration to induce fresh weight and percentage of callus area in the explant. High activity of 2,4 D is able to trigger the stressed of the network and cause cell division continuously affecting the callus size (Dewita, 2015). That happens through increasing osmotic pressure, cell permeability to water, plasticity, protein synthesis, cell wall development, and reduction of cell wall pressure (Robles et al., 2016). The growth regulator, 2,4-D enters to plant explant cells through diffusion at wounds at the ends of the explants. 2,4 D stimulates cell wall softening by activating proton pumps $(\mathrm{H}+$ ions) on the plasma membrane and causing lower acidity in the cell wall. The $\mathrm{pH}$ is close to the $\mathrm{pH}$ on the plasma membrane (about $\mathrm{pH}$ 4.5). The active proton pump can break the hydrogen bonds between the microfibrils of embryonic cellulose wall $C$. pubescens. The breakdown of hydrogen bonds causes the hypocotyl cell wall of $C$. pubescens to stretch easily, so the cell walls pressure decrease and result in the flexing of $C$. pubescens cells. Low acidity can also activate certain enzymes in cell walls that can degrade various proteins or polysaccharides that spread on soft and flexible cell walls, so enlargement of embryonic cells can occur (Hayati et al., 2010).

According to Rahayu et al. (2003), the large fresh weight of callus was caused by the high water content. Besides, the fresh weight of the callus produced also depends on the callus morphology, the speed of the cells dividing, and the enlargement of the callus. An essential property of cytokinins is their stimulation against cell division. Optimal cell division will cause optimal callus growth and will increase callus fresh weight. It will also affect the percentage of callus area in explant because the higher the fresh weight of callus is, the higher of the callus area in explant will be. 
The hormone worked optimally at certain concentrations, and the cell generally contains enough or almost enough hormone to be maintained (Sitorus et al., 2012). Santoso and Nursandi (2004) stated that the addition of cytokines in the form of BAP gave the response to explant embryos of young $C$. pubescens. The cytokines play a significant role in stimulating cell division and callus proliferation. The addition of BAP to culture media may increase the rate of protein synthesis, so it encouraged the cell enlargement and division by increasing the transition from G2 to mitosis.

\section{Morphology and Anatomy of the Embryogenic Callus Carica pubescens}

The embryogenic callus has yellowish, yellowishwhite, brownish-white characteristics, a crumb texture, and having a large nucleus when it is observed microscopically. It can be seen from the morphology and anatomy of callus formed in the explant. The results of callus color and texture observations are presented in Table 1.

The color of the callus is a visual indicator used to determine callus growth and determine the callus whether or not it is included in embryogenic callus characteristics. It is likely because the callus is experiencing a good growth period, so the color result is different. Related to the embryogenic callus formation, Peterson and Smith (1991) explained that a yellowish and shiny white callus characterizes embryogenic callus. Meanwhile, Al-Gendy (2013) stated that embryogenic callus is brownish yellow. The white callus is caused by the callus tissue, which does not contain chloroplasts. It is in line with the opinion of Tsuro et al. (1999) who stated that the white callus is an embryogenic tissue that does not yet contain chloroplasts but high starch granules. The color changes that occur are due to the degradation of color pigmentation.

Embryogenic callus indications are presented in the texture of the resulting callus. The embryonic callus is characterized by crumb callus texture and the callus that has crumb texture and easily separates into single cells. The characteristics of crumb callus texture are having a lot of water content, and easily separated then growing apart into small parts (Sitorus et al., 2012). The formation of crust callus can be influenced by the type of explant and hormone used. Callus with crumb texture is triggered by the presence of endogenous auxin hormone, which is produced internally by explant that has grown to form the callus. According to Zulkarnain and Lizawati (2011), the crumb callus texture indicated embryogenic properties which will develop into somatic embryos. Cell division in the texture of the callus crumbs (friable) is faster than the compact callus texture because the texture of the compact callus undergoes lignification formation (Mahadi et al., 2016).

According to Sitinjak et al. (2006) embryogenic callus induction required a combination of optimum concentrations of 2,4-D and BAP that can increase cell sensitivity from explant tissue to reactivate the cell cycle. It initiates embryo formation or a combination of hormone concentrations which can activate specific genes for callus induction embryogenic. The $7.5 \mathrm{mg} / \mathrm{L} \mathrm{2,4D}$ and $0.5 \mathrm{mg} / \mathrm{L}$ BAP treatment showed embryonic callus with crumb texture. It was characterized by a large core containing starch and plastid grains. It is in line with the opinion of Kasi and Sumaryono (2008) who stated that embryogenic callus had dense and meristematic cells with marked dense cell space, clear cell nucleus, dense cytoplasm and high cell division activity.

\section{Acknowledgement}

Our best gratitude goes to the Department of Biology, Faculty of Science and Technology, Maulana Malik Ibrahim State Islamic University of Malang and all parties involved in this research.

\section{References}

Abidin, Z. (1983). Dasar-dasar pengetahuan tentang zat pengatur tumbuh. Bandung: Angkasa.

Al-Gendy, A., Riham O. B. L., \& Omayma, D. E. (2013). Somatic embryogenesis and plant regeneration from callus and suspension cultures of Iphiona mucronata Forssk. European Science Journal, 9(27), 37-49.

Budiyanti, T., Purnomo, S., Karsinah, F. N., \& Wahyudi, A. (2005). Karakterisasi 88 aksesi pepaya koleksi balai penelitian tanaman buah. Buletin Plasma Nutfah, 11(1), 21-27. doi:10.21082/bpln.v11n1.2005.p21-27

Damayanti, D., Sudarsono, Ika, M., \& Herman, M. (2007). Regenerasi pepaya melalui kultur in vitro. Jurnal AgroBiogen, 3(2), 49-54. doi:10.21082/jbio.v3n2.2007.p49-54

Dewi, S. K. (2009). Analisis strategi pengembangan usaha industri kecil olahan carica (Studi kasus pada industri kecil olahan carica di Kecamatan Mojotengah, Kabupaten Wonosobo) (Skripsi, Institut Pertanian Bogor, 2009). Retrieved from http://repository.ipb.ac.id/handle/123456789/14386

Dewita, R. (2015). Respon eksplan daun Artemisia vulgaris L. terhadap pemberian beberapa konsentrasi BAP dan 2,4-D (Skripsi, Universitas Andalas, 2015). Retrieved from http://scholar.unand.ac.id/id/eprint/2814

Dinas Pertanian Subdin Hortikultura (Distan) Kabupaten Wonosobo. (2008). Deskripsi usulan flora carica (Carica candamarcensis) Kabupaten Wonosobo. Wonosobo: Distan Kabupaten Wonosobo. doi:10.21082/jbio.v3v2. 2007.54

Fithrotin, Y. (2017). Pengaruh pemberian 2,4-Dichlorophenoxy Acetic Acid (2,4-D) dan Bezyladenine (BA) terhadap induksi kalus embriogenik daun ashitaba (Angelica keiskei) (Skripsi, UIN Malang, 2017). Retrieved from http://etheses.uin-malang.ac.id/id/eprint/10720

George, E. F., \& Sherrington, T. D. (1984). Plan Propagation by tissue culture handbook and directory of commercial laboratories. England: Eastern Press.

Haensch, K. T. (2007). Influence of 2,4-D and BAP on callus growth and the subsequent regeneration of somatic embryos in long-term cultures of Pelargonium $x$ domesticum cv. Madame Layal. Electronic Journal of Biotechnology, 10(1), 1-9. doi:10.2225/vol10-issue1fulltext-9

Hayati, S. K., Nurchayati, Y., \& Setiari, N. (2010). Induksi kalus dari hipokotil alfalfa (Medicago sativa L.) secara in vitro dengan penambahan BAP dan NAA. Bioma: Berkala Ilmiah Biologi, 12(1), 6-12. doi:10.14710/bioma.12.1.6-12 
Indria, W. (2017). Pengaruh pemberian zat pengatur tumbuh 2,4 Dikhlorofenoksiasetat $(2,4-\mathrm{D})$ terhadap induksi kalus dan penambahan zat pengatur tumbuh Benzyl Adenine (BA) terhadap induksi kalus embriogenik rumput gajah varietas hawaii (Penissetum purpureum cv. Hawaii) (in vitro). Student e-Journal, 6(1), 1-12.

Kasi, D. P., \& Sumaryono. (2008). Perkembangan kalus embriogenik sagu (Metroxylon sagu Rottb.) pada tiga system kultur in vitro. Menara Perkebunan, 76(1), 1-10. doi:10.22302/iribb.jur.mp.v76i1.88

Khaniyah, S., \& Habibah, N. A. (2012). Pertumbuhan kalus daun dewa (Gynura prochumbens) dengan kombinasi 2,4Dichlorophenoxyacetic acid dan kinetin secara in vitro. Biosantifika:Journal of Biology \& Biology Education, 2(4), 98-105.

Lestari, E. G. (2011). Peranan Zat Pengatur Tumbuh dalam Perbanyakan Tanaman melalui Kultur Jaringan. Jurnal AgroBiogen, 7(1), 63-68. doi:10.21082/jbio.v7i1.2011.p 63-68

Mahadi, I., Syafi'I, W., \& Sari, Y. (2016). Pengaruh pemberian hormon 2,4-D dan BAP terhadappertumbuhan kalus jeruk kasturi (Citrus microcarpa). Jurnal Pendidikan Sains dan Biologi, 12(2), 97-101.

Minarno, E. B. (2015). Skrining fitokimia dan kandungan total flavonoid pada buah Carica pubescens Lenne \& K. Koch Di Kawasan Bromo, Cangar, dan Dataran Tinggi Dieng. El-Hayah, 5(2), 73-82.

Mondal, M., Gupta, S., \& Mukherjee B. B. (1994). Callus culture and planlet production in Carica papaya (Var. Honey Dew). Plant Cell Reports, 13(7), 390-393. doi:10.1007/BF00234144

Neliyati. (2013). Regenerasi embrio somatik tengkawang (Shorea stenoptera Burck) pada beberapa konsentrasi zat pengatur tumbuh GA3 dan BAP. Jurnal Program Studi Agroteknologi, Fakultas Pertanian Unversitas Jambi, 2(2), 82-90.

Ngumriana, R. (2015). Strategi pengembangan agroindustri pepaya gunung (Carica pubescens) studi kasus di UKM X Kabupaten Wonosobo (Skripsi, Institut Pertanian Bogor, 2015) Retrieved from http://repository.ipb.ac.id/handle/123456 $789 / 74920$

Peterson, G., \& Smith, R. (1991). Effect of abscicic acid and callus size on regeneration of american and international rice varietes. Plant Cell Reports, 10(1), 35-38. doi:10.1007/BF00233029

Pratiwi, E., \& Rahayu, T. (2013). Uji hormon NAA dan BAP dalam medium MS untuk pertumbuhan eksplan alfalfa (Medicago sativa L.) dari berbagai sumber eksplan. Jurnal Ilmiah Biosaintropis, 1(1). Retrieved from FMIPA UNISMA.

Quiroz, F., Zeel, M. M, Teyer, F. S., Herrera, R., \& Vargas, L. (2002). Differential gene expression in embryogenic and non-embryogenic clusters from cell suspension cultures of coffea arabica. Journal of Plant Physiology, 159(11), $1267-1270$.

Rahayu, B., Solichatun, S., \& Anggarwulan, E. (2003). Pengaruh asam 2,4-Dichlorophenoxyiacetic acid (2,4-D) terhadap pembentukan dan pertumbuhan kalus serta kandungan flavonoid kultur kalus Acalypa indica L. Biofarmasi Journal of Natural Product Biochemistry, 1(1), 1-6.

Rivai, R. R., Husni, A., \& Purwito, A. (2014). Induksi kalus dan embrio somatik tanaman jambu biji merah (Psidium guajava L.). Buletin Agrohorti, 2(1), 49-58.

Robles-Martine, M., Barba-de la Rosa A. P., Gueraud, F., NegreSalvayre, A., Rossignol, M., \& del Soccoro Santos-Diaz, M. (2016). Establishment of callus and cell suspensions of wild and domesticated opuntia spesies: study in their potential as a source of metabolite production. Plant Cell, Tissue and Organ Culture (PCTOC), 124(1), 181-189. doi:10.1007/s11240-015-0886-0

Rusdianto \& Indrianto, A., (2012). Induksi kalus embriogenik pada wortel (Daucus carota L.) menggunakan 2,4Dichlorophenoxy Acetic Acid (2,4-D). Jurnal Bionature, 13(2), 136-145. doi:10.35580/bionature.v13i2.1439

Santoso, U. \& Nursandi, F. (2004). Kultur Jaringan Tanaman. Malang: UMM Press.

Sari, N., \& Suwarsi, E. (2014). Optimasi jenis dan konsentrasi ZPT dalam induksi kalus embriogenik dan regenerasi menjadi planlet pada Carica pubescens (Lenne \& K. Koch). Biosaintifika: Journal of Biology \& Biology, 6(1), 51-59. doi:10.15294/biosantifika.v6i1.3785

Sitinjak, R. R., Rostiana, O., Karyono, K., \& Supriatun, T. (2006). Pengaruh 2,4-D dan BA terhadap induksi kalus embriogenik pada kultur meristem jahe (Zingiber officinale Rose.). Berita Biologi: Jurnal Ilmu-ilmu Hayati, 8(2), 115120. doi:10.14203/beritabiologi.v812.2037

Sitorus, E., Hastuti, E., dan Setiari, N. (2012). Induksi kalus binahong (Basella rubra L.) secara in vitro pada media murashige \& skoog dengan konsentrasi sukrosa yang berbeda. Bioma: Berkala Ilmiah Biologi, 13(1), 1-7. doi:10.14710/bioma.13.1.1-7

Subarnas, A. (2011). Produksi Katarantin Melalui Kultur Jaringan. Bandung: CV. Lubuk Agung.

Tsuro, M., Koda, M., \& Inoue, M. (1999). Comparation effect of different types of cytocine for shoot formation and plant regeneration in leaf-derived callus of lavender (Lavandura vera DC). Scientia Horticulturae, 81(3), 331-336. doi:10.1016/S0304-4238(99)00003-5

Zulkarnain, Z., \& Lizawati. (2011). Proliferasi kalus dari eksplan hipokotil dan kotiledon tanaman jarak pagar (Jatropha curcas L.) pada pemberian 2,4-D. Jurnal Natur Indonesia, 14(1), 19-25. doi:10.31258/jnat.14.1.1.19-25

Zulkarnain. (2009). Kultur Jaringan Tanaman Solusi Perbanyakan Tanaman Budidaya. Jakarta: PT. Bumi Aksara. 